This work was supported in part by Research Corporation Technologies, Tucson, AZ 85710, USA, and at the Universidad de Sonora by CONACYT, Mexico (Grant No. 0204-E9107-2207).

\section{References}

Bernhardt, P. V. \& Lawrance, G. A. (1990). Coord. Chem. Rev. 104, 297-343.

Cromer, D. T. (1974). International Tables for X-ray Crystallography, Vol. IV, Table 2.3.1. Birmingham: Kynoch Press. (Present distributor Kluwer Academic Publishers, Dordrecht.)
CROMER, D. T. \& WABER, J. T. (1974). International Tables for $X$-ray Crystallography, Vol. IV, Table 2.2B. Birmingham: Kynoch Press. (Present distributor Kluwer Academic Publishers, Dordrecht.)

FAIR, C. K. (1990). MolEN. An interactive structure solution procedure. Enraf-Nonius, Delft, The Netherlands.

Inoue, M. B., Villegas, C. A., Asano, K., Nakamura, M., InOue, M. \& Fernando, Q. (1992). Inorg. Chem. 31, 2480 2483.

JoHnson, C. K. (1965). ORTEP. Report ORNL-3794. Oak Ridge National Laboratory, Tennessee, USA.

PARKer, D. (1990). Chem. Br. pp. 942-945.

Wells, A. F. (1984). Structural Inorganic Chemistry, 5th ed., p. 78. Oxford: Clarendon Press.

Acta Cryst. (1993). C49, 878-881

\title{
Structure of Hydroxo(methyl)bis $\left(\eta^{5}\right.$-pentamethylcyclopentadienyl)tantalum(V) Hydroxotris(pentafluorophenyl)borate
}

\author{
By William P. Schaefer, Roger W. Quan and John E. Bercaw \\ Division of Chemistry and Chemical Engineering* and The Beckman Institute, Mail Code 139-74, \\ California Institute of Technology, Pasadena, California 91125, USA
}

(Received 30 September 1991; accepted 7 April 1992)

Abstract. $\quad\left[\mathrm{Ta}\left(\mathrm{C}_{10} \mathrm{H}_{15}\right)_{2}(\mathrm{OH})\left(\mathrm{CH}_{3}\right)\right]\left[\mathrm{B}(\mathrm{OH})\left(\mathrm{C}_{6} \mathrm{~F}_{5}\right)_{3}\right]$, $M_{r}=1001.63$, monoclinic, $P 2_{1} / n, a=12.217$ (2), $b=$ 16.848 (6), $c=18.834(3) \AA, \quad \beta=100.37(2)^{\circ}, \quad V=$ $3813.1(15) \AA^{3}, Z=4, D_{x}=1.75 \mathrm{~g} \mathrm{~cm}^{-3}, \lambda($ Mo $K \alpha)$ $=0.71073 \AA, \mu=29.52 \mathrm{~cm}^{-1}, F(000)=1972$, room temperature, $R=0.031$ for 3534 reflections with $F_{o}^{2}$ $>3 \sigma\left(F_{o}^{2}\right)$. The Ta cation has the expected geometry, with $\mathrm{Ta}-\mathrm{C}$ and $\mathrm{Ta}-\mathrm{O}$ distances $2.211(6)$ and $1.865(5) \AA$, respectively. The anion has not been characterized previously; its geometry is irregular with tetrahedral angles at boron ranging from $103.6(6)$ to $113.8(6)^{\circ}$, and systematic angular distortions in the $\mathrm{C}_{6} \mathrm{~F}_{5}$ rings.

Introduction. Recent interest in the reactive oxo chemistry of organometallic complexes has increased due to the possible roles of these compounds in the activation of hydrocarbons by the $2+2$ addition of an aliphatic or aryl $\mathrm{C}-\mathrm{H}$ bond to the metal oxo moiety. Bent metallocene complexes which would model this reaction chemistry, $\left[\left(\eta^{5}-\mathrm{C}_{5} \mathrm{H}_{5}\right)_{2-}\right.$ $\left.\mathrm{Zr}(\mathrm{OH})\left(\mathrm{C}_{6} \mathrm{~F}_{5}\right)\right]$ (Chaudhari \& Stone, 1966), $\left[\left(\eta^{5}-\mathrm{C}_{5} \mathrm{Me}_{5}\right)_{2} \mathrm{Hf}(\mathrm{OH}) \mathrm{Ph}\right]$ (van Asselt, Santarsiero \& Bercaw, 1986; Vaughn, Rupert \& Hillhouse, 1987), [( $\left.\left.\eta^{5}-\mathrm{C}_{5} \mathrm{Me}_{5}\right)_{2} \mathrm{Zr}(\mathrm{OH}) \mathrm{Ph}\right]$ (Schrock \& Marks, 1988) and $\left[\left(\eta^{5}-\mathrm{C}_{5} \mathrm{Me}_{5}\right)_{2} \mathrm{Zr}(\mathrm{OH})\left\{\mathrm{CPh}=\mathrm{CPhNH}\left(\mathrm{N}=\mathrm{CPh}_{2}\right)\right\}\right]$

\footnotetext{
* Contribution No. 8514 .
}

0108-2701/93/050878-04\$06.00
(Vaughn, Hillhouse \& Rheingold, 1990), have been synthesized by routes which do not involve $2+2$ addition chemistry.

We have been investigating the reaction chemistry of the cation $\left[\left(\eta^{5}-\mathrm{C}_{5} \mathrm{Me}_{5}\right)_{2} \mathrm{Ta}\left(\mathrm{CH}_{3}\right)_{2}\right]^{+}$with a variety of counterions. Initial attempts to prepare this cation with perfluorotetraphenylborate as the counterion by the metathesis of $\left[\left(\eta^{5}-\mathrm{C}_{5} \mathrm{Me}_{5}\right)_{2} \mathrm{Ta}\left(\mathrm{CH}_{3}\right)_{2}\right] \mathrm{SO}_{3} \mathrm{CF}_{3}$ with $\left[\mathrm{NaB}\left(\mathrm{C}_{6} \mathrm{~F}_{5}\right)_{4}\right]$ resulted in the isolation of a crystal found to be $\left[\left(\eta^{5}-\mathrm{C}_{5} \mathrm{Me}_{5}\right)_{2} \mathrm{Ta}(\mathrm{OH})\left(\mathrm{CH}_{3}\right)\right]-$ $\left[\mathrm{B}(\mathrm{OH})\left(\mathrm{C}_{6} \mathrm{~F}_{5}\right)_{3}\right]$. The crystal structure of this complex is described herein.

Experimental. Material synthesized by RWQ; pale orange crystal, irregular chunk with maximum dimensions $0.26 \times 0.35 \times 0.48 \mathrm{~mm}$; CAD- 4 diffractometer, $\omega$ scans; 25 reflections with $34<2 \theta<37^{\circ}$ used for cell dimensions; absorption correction based on $\psi$ scans of three reflections and their Friedel mates, with relative transmission from 0.857 to $1.081 ;(\sin \theta / \lambda)_{\max }$ of $0.54 \AA^{-1}, h$ from -13 to $0, k$ from -18 to $18, l$ from -20 to 20 ; three standard reflections $(\overline{3} 03,015,025)$ showed no variation greater than predicted by counting statistics; 10622 reflections measured, 4975 independent; goodness-offit for merging was 1.10 ( $R_{\text {merge }}$ for 3831 reflections with exactly two observations 0.032 ); all reflections used in solution and refinement of the structure.

(C) 1993 International Union of Crystallography 
Position of Ta atoms found from Patterson map, remaining atoms located by successive structure factor-Fourier calculations; values of $F^{2}$ (positive and negative) used in least-squares refinement; $\mathrm{H}$-atom positions obtained from difference maps calculated in their expected planes, with atoms placed at idealized positions except on $\mathrm{OH}$ groups; isotropic displacement parameters for $\mathrm{H}$ atoms assigned as 1.2 times the equivalent isotropic displacement parameter of the bound $\mathrm{C}$ atom; $\mathrm{H}$ atoms of $\mathrm{Cp}^{*} 2\left(\mathrm{Cp}^{*}=\right.$ pentamethylcyclopentadienyl) were disordered in two sets, arbitrarily given populations of 0.5 each; $\mathrm{H}$-atom parameters not refined, but adjusted once near the conclusion of refinement; positional and anisotropic displacement parameters refined in one full matrix for all other atoms, plus a scale factor and a secondary-extinction parameter (524 parameters). Weights taken as $1 / \sigma^{2}\left(F_{o}{ }^{2}\right)$. Final $R$ (on $F$ ) for 4601 reflections with $F_{o}^{2}>0$ was 0.049 , for 3534 reflections with $F_{o}^{2}>3 \sigma\left(F_{o}^{2}\right), R=0.031, w R$ (on $\left.F^{2}\right)=0.004$, final goodness-of-fit for 4975 total reflections was 1.45 . Variances $\left[\sigma^{2}(I)\right]$ derived from counting statistics plus an additional term, $(0.014 I)^{2}$; variances of the merged data by propagation of error plus another additional term, $(0.014 \bar{l})^{2}$. In final leastsquares refinement, ratio of maximum shift to e.s.d. in any parameter was 0.23 ; final difference map had peaks of $0.65 \mathrm{e} \AA^{-3}$ and holes of up to $0.75 \mathrm{e} \AA^{-3}$. The secondary-extinction parameter [Larson (1967), equation (3)] refined to $0.016(9) \times 10^{-6}$. Atomic scattering factors and anomalous-dispersion corrections $\left(f^{\prime}\right)$ were taken from Cromer \& Waber (1974) and Cromer (1974). Computer programs used were those of the CRYM crystallographic computing system (Duchamp, 1964) and ORTEP (Johnson, 1976). Final refined parameters of the atoms are listed in Table $1 . \dagger$

Discussion. The Ta-bis $\left(\mathrm{Cp}^{*}\right)$ cation in this structure (Fig. 1) resembles closely other such species whose structures we have determined (van Asselt, Trimmer, Henling \& Bercaw, 1988; Schaefer, Henling, Quan \& Bercaw, 1991). The Ta-Cp* centroid distances $(2.151,2.153 \AA)$ are at the short end of the normal range and the centroid-Ta-centroid angle $\left(137.3^{\circ}\right)$ is essentially the same as the average found for eight other structures $\left(138.0^{\circ}\right)$. (The centroids are the averages of the five ring $\mathrm{C}$-atom coordinates.) The $\mathrm{Ta}-\mathrm{O}(\mathrm{H})$ distance, $1.864(5) \AA$, is comparable to those we have found earlier [average of three,

\footnotetext{
$\dagger$ Lists of anisotropic displacement parameters, complete distances and angles, structure factors and assigned $\mathrm{H}$-atom parameters have been deposited with the British Library Document Supply Centre as Supplementary Publication No. SUP 55366 (30 pp.). Copies may be obtained through The Technical Editor, International Union of Crystallography, 5 Abbey Square, Chester CH1 2HU, England. [CIF reference: HH0591]
}

Table 1. Final heavy-atom parameters $\left(\times 10^{4}\right)$ for the title compound

\begin{tabular}{|c|c|c|c|}
\hline$x$ & $y$ & $z$ & $U_{\mathrm{eq}}\left(\AA^{2}\right)$ \\
\hline $1416(.2)$ & $2186(.2)$ & $1866(.1)$ & 448 (1) \\
\hline $561(4)$ & $1263(3)$ & $1786(2)$ & 811 (15) \\
\hline$-44(5)$ & 2978 (4) & $1605(3)$ & 621 (19) \\
\hline $3025(6)$ & $2353(5)$ & $1246(3)$ & $627(21)$ \\
\hline $2512(6)$ & $1616(4)$ & $1058(3)$ & $516(18)$ \\
\hline $1471(7)$ & $1766(5)$ & $623(4)$ & $625(22)$ \\
\hline $1310(7)$ & $2589(6)$ & $587(4)$ & $721(25)$ \\
\hline $2260(8)$ & 2944 (4) & $982(4)$ & $667(22)$ \\
\hline $4247(7)$ & $2497(6)$ & $1493(4)$ & $1067(31)$ \\
\hline $3042(8)$ & $813(5)$ & $1200(4)$ & $1009(28)$ \\
\hline $683(7)$ & $1154(6)$ & $252(4)$ & $1127(31)$ \\
\hline $381(9)$ & $3008(7)$ & $104(5)$ & $1473(41)$ \\
\hline $2482(10)$ & $3839(5)$ & $979(5)$ & $1370(39)$ \\
\hline $1046(6)$ & $2193(5)$ & $3100(3)$ & $655(18)$ \\
\hline $1392(7)$ & $2978(4)$ & $2978(3)$ & $624(22)$ \\
\hline $2502(6)$ & 2959 (4) & $2880(3)$ & $551(19)$ \\
\hline $2861(6)$ & 2161 (5) & 2951 (3) & $620(18)$ \\
\hline $1972(7)$ & $1699(4)$ & 3099 (4) & $631(2 \mathrm{I})$ \\
\hline$-48(7)$ & $1938(5)$ & $3271(5)$ & $1018(27)$ \\
\hline $753(7)$ & $3728(5)$ & 3055 (4) & 941 (27) \\
\hline $3225(7)$ & $3682(5)$ & $2875(4)$ & $822(24)$ \\
\hline $4042(7)$ & $1862(5)$ & $3069(4)$ & $930(27)$ \\
\hline $2033(8)$ & $822(5)$ & $3275(4)$ & $1100(32)$ \\
\hline $8085(7)$ & $115(5)$ & $1816(5)$ & $631(25)$ \\
\hline $9307(4)$ & $111(3)$ & $1827(3)$ & $833(19)$ \\
\hline $7668(5)$ & $955(4)$ & $1407(4)$ & $500(18)$ \\
\hline $7366(6)$ & $1644(4)$ & $1693(4)$ & $600(20)$ \\
\hline $7147(6)$ & $2349(4)$ & $1331(5)$ & $685(25)$ \\
\hline $7198(7)$ & $2378(5)$ & $612(5)$ & $783(26)$ \\
\hline $7493(6)$ & $1722(5)$ & $282(4)$ & $690(23)$ \\
\hline $7721(6)$ & $1036(4)$ & $676(4)$ & $626(21)$ \\
\hline $7312(4)$ & $1679(2)$ & $2406(2)$ & $887(14)$ \\
\hline $6883(4)$ & $3005(2)$ & $1678(3)$ & $1034(17)$ \\
\hline $6981(4)$ & 3067 (3) & $250(3)$ & $1137(17)$ \\
\hline $7578(5)$ & $1754(3)$ & $-414(2)$ & $1148(17)$ \\
\hline $8028(4)$ & $408(3)$ & $305(2)$ & $926(14)$ \\
\hline $7512(6)$ & $-689(4)$ & $1387(4)$ & $561(19)$ \\
\hline $6535(6)$ & $-738(4)$ & $893(4)$ & $617(21)$ \\
\hline $6098(7)$ & $-1418(5)$ & $536(4)$ & $686(23)$ \\
\hline $6695(8)$ & $-2097(5)$ & $661(4)$ & 709 (22) \\
\hline $7662(7)$ & $-2111(5)$ & $1153(4)$ & $710(23)$ \\
\hline $8031(6)$ & $-1415(4)$ & $1496(4)$ & $612(21)$ \\
\hline 5899 (3) & $-76(3)$ & $730(2)$ & 887 (15) \\
\hline $5152(4)$ & $-1400(3)$ & $73(2)$ & $1077(16)$ \\
\hline $6311(4)$ & -2778 & $322(2)$ & $1085(15)$ \\
\hline $8225(4)$ & -2789 & 1281 & $1070(16)$ \\
\hline 8991 (4) & $-1474(2)$ & $1990(3)$ & $885(15)$ \\
\hline $7778(7)$ & $50(4)$ & $2637(4)$ & $672(23)$ \\
\hline $6708(8)$ & $120(4)$ & $2758(4)$ & $722(25)$ \\
\hline $6416(10)$ & $37(5)$ & $3430(6)$ & 949 (34) \\
\hline $7211(15)$ & $-123(7)$ & $4003(6)$ & $1259(53)$ \\
\hline $8265(13)$ & $-217(7)$ & $3938(8)$ & $1282(50)$ \\
\hline $8532(10)$ & $-137(5)$ & $3254(6)$ & $974(32)$ \\
\hline 5884 (4) & $292(2)$ & 2198 & $835(13)$ \\
\hline $5301(6)$ & $124(3)$ & $3483(3)$ & $1362(21)$ \\
\hline $6830(7)$ & $-218(3)$ & $4653(3)$ & $1792(29)$ \\
\hline $9019(7)$ & $-384(4)$ & $4512(3)$ & $1927(30)$ \\
\hline $9625(5)$ & $-266(3)$ & $3226(3)$ & $1377(22)$ \\
\hline
\end{tabular}

1.889 (31) $\AA$ ] and the Ta-C distance, 2.211 (6) $\AA$, is slightly shorter than $\mathrm{Ta}-\mathrm{C}$ distances to benzyl $\mathrm{C}$ atoms $[2.323(9)$ and $2.299(5) \AA]$. The $\mathrm{C}-\mathrm{Ta}-\mathrm{O}$ angle of $93.8(2)^{\circ}$ is again as expected from other work. The methyl group is $55^{\circ}$ to one side of the centroid-Ta-centroid plane, while the $\mathrm{OH}$ group is $39^{\circ}$ on the other side. In the $\mathrm{Cp}^{*}$ rings, the $\mathrm{C}-\mathrm{C}$ distances average $1.405(8) \AA$, the $\mathrm{C}-\mathrm{CH}_{3}$ distances average 1.506 (11) $\AA$ and the average deviation of an internal angle from $108^{\circ}$ is $0.8^{\circ}$; all these are normal values for $\mathrm{Cp}^{*}$ groups.

The $\mathrm{O} 1$ (on $\mathrm{Ta}$ ) to $\mathrm{O} 2$ (on $\mathrm{B}$ ) distance is quite short, 2.483 (7) $\AA$, indicating a strong hydrogen bond between these $\mathrm{O}(\mathrm{H})$ groups. $\mathrm{Ol}$ has no other 
neighbor closer than $3.5 \AA$, whereas $\mathrm{O} 2$ has a close approach to F36 [2.671 (7) compared to $2.75 \AA$ for a van der Waals contact]. Thus we expect $\mathrm{O} 1$ to donate a hydrogen bond to $\mathrm{O} 2$ and $\mathrm{O} 2$ to donate a weak one to F36. The angles involved are satisfactory. Because we did not locate these $H$ atoms in difference maps, we can only surmise about the situation.

The hydroxotris(pentafiuorophenyl)borate anion shows marked departures in structure from what we had anticipated. We find no references in the Cambridge Structural Database (Allen, Kennard \& Taylor, 1983) to this species and only one to a hydroxo(triphenyl)borate (von Dueten, von Schlabrendorff \& Klar, 1980), but that is not an isolated ion, so even the $\mathrm{B}-\mathrm{O}$ distances are not comparable. We find $\mathrm{B}-\mathrm{O}$ to be 1.490 (10) $\AA$, shorter than the 1.540 (7) $\AA$ reported by von Deuten et al. Such a difference is to be expected; the $\mathrm{B}-\mathrm{O}$ bond will be longer if the $\mathrm{O}$ atom is bonded to another group - in the example of von Deuten et al., an $\mathrm{N}$ atom in an ethylnitrosolato group. The B-C distances in their triphenylborate ion average 1.628 (13) $\AA$, shorter by $0.029 \AA$ than the 1.657 (9) $\AA$ we found. Our $C-C$ and $\mathrm{C}-\mathrm{F}$ distances in the pentafluorophenyl rings are normal [1.370 (17) and $1.353(22) \AA]$ but the rings show systematic angular distortions related to their substitution, particularly for the $\mathrm{C}-\mathrm{C}-\mathrm{C}$ angle adjacent to $\mathrm{BOH}$ at $112.1(7)^{\circ}$ (Domenicano, Vaciago \& Coulson, 1975). As explained by Domenicano et al., an electron-donating substituent on a benzene ring leads to a smaller endocyclic angle at the $\mathrm{C}$ atom bonded to the substituent and for electron-withdrawing substituents the reverse is true.

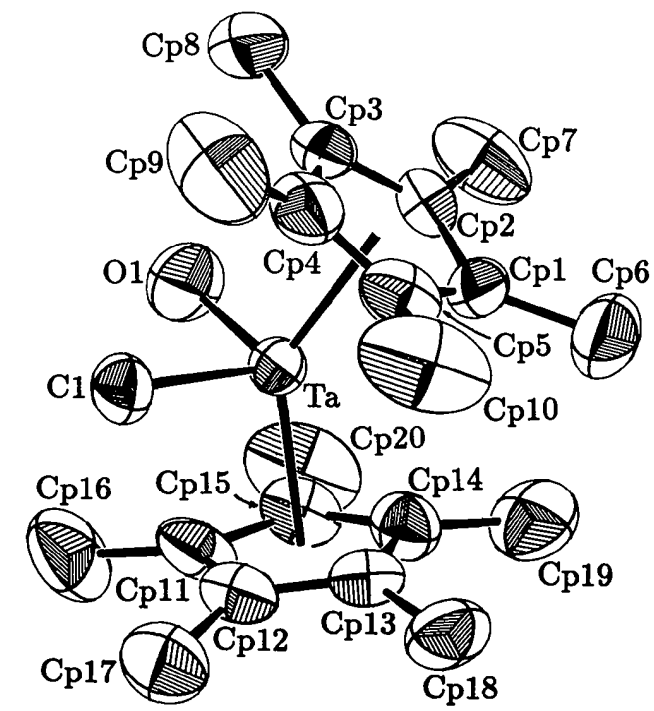

Fig. 1. An ORTEP drawing of the cation showing the atomnumbering system with thermal ellipsoids at the $50 \%$ probability level.
Table 2. Selected distances $(\AA)$ and angles $\left(^{\circ}\right)$ for the title compound

\begin{tabular}{|c|c|c|c|}
\hline $\mathrm{Ta}-\mathrm{Cl}$ & $2.211(6)$ & $\mathrm{B}-\mathrm{O} 2$ & $1.490(10)$ \\
\hline $\mathrm{Ta}-\mathrm{Ol}$ & $1.865(5)$ & $\mathrm{B}-\mathrm{Cll}$ & $1.648(11)$ \\
\hline $\mathrm{Ta}-\mathrm{Cp} \mathrm{p}_{1}$ & $2.151(1) \dagger$ & $\mathrm{B}-\mathrm{C} 21$ & $1.665(11)$ \\
\hline $\mathrm{Ta}-\mathrm{Cp}^{*} 2$ & $2.153(1)$ & $B-C 31$ & 1.658 (11) \\
\hline $\mathrm{Ol}-\mathrm{Ta}-\mathrm{Cl}$ & $93.8(2)$ & $\mathrm{C} 11-\mathrm{B}-\mathrm{O} 2$ & $103.6(6)$ \\
\hline$C p^{* 1}-\mathrm{Ta}-\mathrm{Cp}^{* 2} 2$ & 137.3 & $\mathrm{C} 21-\mathrm{B}-\mathrm{O} 2$ & $109.6(6)$ \\
\hline 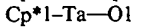 & $106.3(1)$ & $\mathrm{C} 31-\mathrm{B}-\mathrm{O} 2$ & $112.5(6)$ \\
\hline $\mathrm{Cp} * 1-\mathrm{Ta}-\mathrm{Cl}$ & $101.9(2)$ & $\mathrm{C} 21-\mathrm{B}-\mathrm{C} 11$ & $113.8(6)$ \\
\hline $\mathrm{Cp}^{*} 2-\mathrm{Ta}-\mathrm{Ol}$ & $106.6(1)$ & $\mathrm{C} 31-\mathrm{B}-\mathrm{C} 11$ & $112.9(6)$ \\
\hline $\mathrm{Cp}^{* 2-\mathrm{Ta}-\mathrm{Cl}}$ & $102.3(2)$ & $\mathrm{C} 31-\mathrm{B}-\mathrm{C} 21$ & $104.7(6)$ \\
\hline
\end{tabular}

$\dagger \mathrm{Cp}^{*} 1$ and $\mathrm{Cp} * 2$ are the centroids of the five $\mathrm{C}$ atoms of the $\mathrm{Cp}^{*}$ rings.

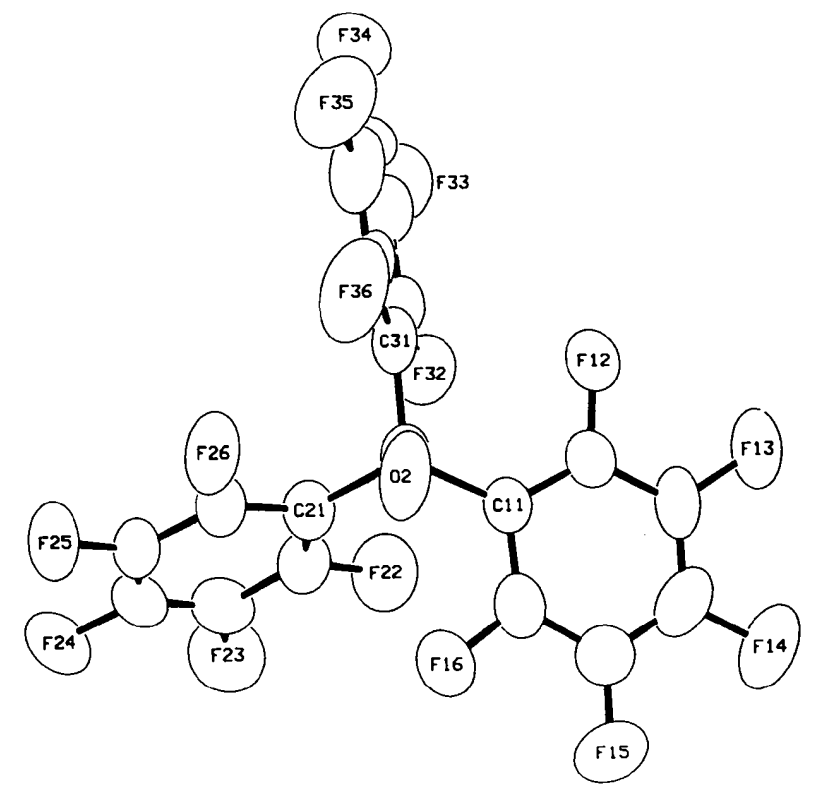

Fig. 2. An $O R T E P$ drawing of the tris(pentafluorophenyl)borate anion with the atom-numbering system indicated ( $\mathrm{F} 12$ bonded to $\mathrm{C} 12$, etc.). The view is perpendicular to the plane of $\mathrm{C} 11, \mathrm{C} 21$ and $\mathrm{C} 31$ and the ellipsoids are shown at the $50 \%$ probability level.

In this anion we have two types of substituents, $\mathrm{F}$ atoms and a $\mathrm{BOH}$ group. The $\mathrm{F}$ atoms all tend to increase the angle at their $\mathrm{C}$ atom and since there are five the remaining endocyclic angle is reduced, generally by $3-4^{\circ}$ (Domenicano et al., 1975). The $\mathrm{BOH}$ group is an electron-releasing group and its tendency will be to reduce the endocyclic angle at the $\mathrm{C}$ atom to which it is bonded. Thus the two effects reinforce each other and the result is an average angle of $112.1(7)^{\circ}$ in the three phenyl rings, close to the smallest observed in the phenyl rings of tetraphenylborate ions. The Cambridge Structural Database (Allen et al., 1983) contains 301 examples of such ions, with the smallest endocyclic angle at the $\mathrm{C}$ atom bonded to the $\mathrm{B}$ atom being $111.2^{\circ}$ and 35 (of 1204 angles) being smaller than $113^{\circ}$. The adjacent angles in all three rings expand to an average value of $125.2(9)^{\circ}$ to maintain the planarity of the group 
(the sums of the interior angles are 719.9, 720.0 and $\left.719.9^{\circ}\right)$. The $\mathrm{B}$ atom is in the plane of the phenyl ring as shown by the sum of the angles at the $\mathrm{C}$ atom bonded to it $\left(359.6,359.9\right.$ and $\left.359.7^{\circ}\right)$. The three pentafluorophenyl groups, instead of being propeller blades about the $\mathrm{B}-\mathrm{O}$ axis, are each oriented differently. The plane of the first is almost perpendicular to that axis, the plane of the second is at an angle of about $20^{\circ}$ and the plane of the third is nearly parallel to it (Fig. 2). The B $\cdots o-F$ distances range from 2.88 to $3.07 \AA$, all greater than van der Waals contacts, but the $\mathrm{O} 2 \cdots \mathrm{F} 26$ and $\mathrm{O} 2 \cdots \mathrm{F} 36$ distances are short, 2.723 (6) and 2.671 (7) $\AA$, respectively, compared to $2.75 \AA$ for a van der Waals contact.

This work was supported by the National Science Foundation (Grant No. CHE-8901593) and Shell Companies Foundation. We thank Professor Håkon Hope for useful advice concerning the geometry of the pentafluorophenyl groups.

\section{References}

Allen, F. H., Kennard, O. \& Taylor, R. (1983). Acc. Chem. Res. 16, 146-153.
Asselt, A. van, Santarsiero, B. D. \& Bercaw, J. E. (1986). $J$. Am. Chem. Soc. 108, 8291-8293.

Asselt, A. van, Trimmer, M. S., Henling, L. M. \& Bercaw, J. E. (1988). J. Am. Chem. Soc. 110, 8254-8255.

Chaudhari, M. \& Stone, F. G. A. (1966). J. Chem. Soc. A, pp. $838-841$.

Cromer, D. T. (1974). International Tables for X-ray Crystallography, Vol. IV, pp. 149-151. Birmingham: Kynoch Press. (Present distributor Kluwer Academic Publishers, Dordrecht.)

Cromer, D. T. \& WABER, J. T. (1974). International Tables for $X$-ray Crystallography, Vol. IV, pp. 99-101. Birmingham: Kynoch Press. (Present distributor Kluwer Academic Publishers, Dordrecht.)

Deuten, K. von, von Schlabrendorff, C. \& Klar, G. (1980). Cryst. Struct. Commun. 9, 753-759.

Domenicano, A., Vaciago, A. \& Coulson, C. A. (1975). Acta Cryst. B31, 221-234.

Duchamp, D. J. (1964). Proc. Am. Crystallogr. Assoc. Meet. Bozeman, Montana, p. 29. Abstract B-14.

JOHNSON, C. K. (1976). ORTEPII. Report ORNL-5138. Oak Ridge National Laboratory, Tennessee, USA.

Larson, A. C. (1967). Acta Cryst. 23, 664-665.

Schaefer, W. P., Henling, L. M., Quan, R. W. \& Bercaw, J. E. (1991). Unpublished work.

Schrock, L. E. \& Marks, T. J. (1988). J. Am. Chem. Soc. 110, 7701-7715.

Vaughn, G. A., Hillhouse, G. L. \& Rheingold, A. L. (1990). $J$. Am. Chem. Soc. 112, 7994-8001.

Vaughn, G. A., Rupert, P. B. \& Hillhouse, G. L. (1987). J. Am. Chem. Soc. 109, 5538-5539.

Acta Cryst. (1993). C49, 881-884

\title{
Bis[di(imidazol-2-yl)phosphinato- $N^{3}, N^{3}$ |platinum(II) Tetrahydrate
}

\author{
By James F. Britten, Colin J. L. Lock* and Zhixian Wang \\ Laboratories for Inorganic Medicine, Departments of Chemistry and Pathology, McMaster University, \\ ABB-266A Hamilton, Ontario, Canada L8S $4 M 1$
}

(Received 14 July 1992; accepted 18 December 1992)

\begin{abstract}
Pt}\left\{\left(\mathrm{C}_{3} \mathrm{H}_{3} \mathrm{~N}_{2}\right)_{2} \mathrm{O}_{2} \mathrm{P}\right\}_{2}\right] \cdot 4 \mathrm{H}_{2} \mathrm{O}, \quad M_{r}=661.4$, triclinic, $\quad P \overline{1}, \quad a=7.473(1), \quad b=7.779(2), \quad c=$ 9.787 (2) $\AA, \quad \alpha=109.46(3), \quad \beta=98.56(3), \quad \gamma=$ $98.29(3)^{\circ}, V=518.9(3) \AA^{3}, Z=1, D_{m}=2.11(1), D_{x}$ $=2.116 \mathrm{Mg} \mathrm{m}^{-3}, \quad \lambda($ Mo $K \alpha)=0.71073 \AA, \quad \mu=$ $7.038 \mathrm{~mm}^{-1}, \quad F(000)=320, \quad T=293(1) \mathrm{K}, \quad R=$ $0.0268, w R=0.0324$ for 4521 unique reflections and 136 parameters. The ligand molecule is chelated through the N(3) atoms of the imidazole rings to the $\mathrm{Pt}$ atom, which lies on an inversion centre. Bond lengths and angles are normal.
\end{abstract}

Introduction. We have previously prepared di(imidazol-2-yl)phosphinic acid (Howard-Lock, Lock, Penny \& Turner, 1989) and characterized

* To whom correspondence should be addressed. some of its iron, copper and zinc complexes (Seidel, 1990). Ball, Brown \& Cocho (1984) have prepared the zinc complex of a related $\mathrm{C}(4), \mathrm{C}(5)$-substituted acid and characterized the compound by X-ray crystallography. In all these complexes the metal is bound to the $N(3)$ atom of one of the rings and to one of the $\mathrm{O}$ atoms of the phosphinate group. This is hardly surprising, since the acid exists in the zwitterion form. Both $\mathrm{N}$ atoms in the second imidazole ring are protonated, and thus unavailable for coordination. It was of interest, therefore, to prepare a platinum(II) complex of this acid in which one might obtain an $\mathrm{N}_{2} \mathrm{O}_{2}$ coordination arrangement. We were unsuccessful, however, and the title compound was obtained instead. The compound was prepared by the direct reaction of aqueous solutions of phosphinic acid $(0.2 \mathrm{~g}$ in $10 \mathrm{~mL})$ and potassium tetrachlo-

(C) 1993 International Union of Crystallography 